\title{
Determinants of Financial Benefits of Inter-Organizational Relationship Marketing between International Travel Companies
}

\author{
Mai Ngoc Khuong \\ International University - VNU-HCMC \\ E-Mail: mnkhuong@hcmiu.edu.vn
}

\begin{abstract}
This study examines the financial benefits of inter-organizational relationship marketing between two groups of international travel companies in Vietnam and Thailand. A quantitative approach with statistical techniques, including factor and multiple regression analyses were employed. The unit of analysis was at the corporate level with the target population of all Vietnamese international travel companies having relationships with Thai travel partners. The returned sample $(n=114)$ had a response rate of $51.8 \%$. The study found that in order to achieve better financial benefits of the relationship, travel companies should participate in planning and goal setting, show more commitment, have a high frequency of interaction, pay attention to organizational compatibility; formalize the relationship, and have good coordination of the relationship with partners. In addition, the results provide empirical evidence that factors of commitment, frequency of interaction, and coordination significantly contribute to predict the financial benefits of the relationship.
\end{abstract}

Keywords: Relationship Marketing, Financial Benefits of Relationship, VietnamThailand Tourism

\section{INTRODUCTION}

There is a conventional consensus that when a company successfully joins an alliance or partnership, it will generate favorable financial results. However, recent research in the field of inter-organizational relationship and relationship marketing provides inconsistent evidence to explain this effect. For example, Kalwani and Narayandas (1995) and Colgate and Danaher (2000) suggest that firms are often 
disappointed with the results of relationship marketing or activities that seek to establish, develop, and maintain successful relationship with partners (Morgan and Hunt, 1994). On the contrary, Palmatier et al. (2007) states that successful inter-organizational relationships are important to a company's financial performance and directly enhance sales and profits. In addition, Ghosh, et al. (2004) found that industrial distributors expected to obtain financial benefits by reducing operational costs and increasing profits and competitive benefits by improving products and services for customers.

Much research has confirmed the competitive advantages and effectiveness of the relationship marketing as a whole. For instant, the works of Dwyer, Schurr, and Oh (1987), Johanson, Hallen, and Seyed-Mohamed (1991), and Wilson (1995) have been applied in the context of business-to-business marketing and channel relationships (Boyle, et. al., 1992; Ganesan, 1994; Weitz and Jap, 1995). Arnett et al. (2003) examined relationships that are primarily economic in nature, involve business-to-business marketing, and involve for-profit firms. Unfortunately, there has been a lack of research on the financial benefits of relationship marketing between business organizations such as international travel companies.

This research aims to empirically confirm and test whether organizations satisfy with financial benefits (economic value) gained from relationships with partners and to determine what factors are most powerful in predicting financial benefits of organizations after joining alliances or partnering relationships. Thus, this research focuses on enhancing understanding of the inter-organizational relationship as a whole in terms of organizational financial benefits. In addition, this study also aims to identify the determinants of the financial benefits of relationship marketing at the organizational level in the context of travel and tourism and to measure financial benefits of the relationship marketing through independent variables of trust in the relationship, commitment to the relationship, interdependence, coordination of the relationship, communication in the relationship, participation in the relationship, formalization in the relationship, flexibility in the relationship, importance of the relationship, organizational compatibility.

\section{LITERATURE REVIEW}

Relationship marketing research operates according to the paradigm that firms should invest in relationship marketing in order to build better relationships. Marketing scholars study the nature and scope of relationship marketing and develop conceptual frameworks relating to the value of the cooperative and collaborative 
relationship between buyers and sellers as well as the relationship between different marketing actors. The growing trend of partnering with customers, suppliers, and other service partners is not unique to only one industry. In fact, relational partnerships, alliances and other relationship marketing practices are becoming increasingly popular in many industries, for instance, airlines, automobiles, computers, financial services, hospitality, and especially travel and tourism.

De Wulf, Odekerrken-Schoroder, and Iacobucci (2001) state that relationship marketing can bring positive financial outcomes to participating companies. According to Palmatier et al. (2007), financial outcomes or performance can be measured through the proportion of potential sales, the buyer's expressed willingness to pay a price premium, and sales growth. Palmatier and associates define the financial benefits of relationship marketing as "the provision of direct economic benefits in exchange for past or future customer loyalty, include[ing] special discounts, free products to generate incremental sales, and other incentives that may easily be converted to cost savings" (Palmatier et al., 2007, p. 212-213). More specifically, this present study defines the financial benefits of the relationship as the actual economic value of the success of the relationship (Medina-Munoz and Garcia-Falcon, 2000).

The financial benefits of relationship marketing include increased revenue and lower marketing cost (Berry, 1995). In addition, a firm can cut costs by reducing some of the wasteful marketing practices associated with competitive mass marketing and by allowing partners to process orders, design products, and management information directed to the firm (Sheth and Parvatiyar, 1995).

Examining restaurant suppliers and customers, Kim and Gregoire (2006) found that relationships with suppliers and customers play an important role in providing value and lead to high financial performance. In addition, Palmatier et al. (2007) conducted a comparative longitudinal research on the business-to-business relationship between a major Fortune 500 company and its local distributors for three years with returned sample sizes of 984, 1004, and 1089, respectively. This research was based on four theoretical perspectives of inter-organizational relationship: commitment-trust, dependence, transaction cost economics, and relational norms. They found that factors of commitment, interdependence, seller relationship-specific investment, and relational norms had strong effects on overall financial performance, but there was no significant impact of trust on the overall financial performance. 
Others factors derived from the literature on relationship marketing and interorganizational relation include commitment to the relationship, communication, conflict resolution, coordination, flexibility, formalization, frequency of interaction, importance of the relationship, inter-dependence, organizational compatibility, participation, and trust.

- Commitment to the relationship is defined as "an exchange partner believing that an ongoing relationship with another is so important as to warrant maximum efforts at maintaining it; that is, the committed party believes the relationship is worth working on to ensure that it endures indefinitely" (Morgan and Hunt, 1994, p. 23).

- Communication in the relationship refers to the formal as well as informal sharing of meaningful and timely information between firms (Anderson and Narus, 1990).

- Conflict resolution in the partnership is defined as disagreements between inter-organizational relation participants (Dwyer et al., 1987). Conflict resolution in the partnership includes joint problem solving (Thomas, 1976, Cumming, 1984), persuasion (Duetsch, 1969), domination (Mohr and Spekman, 1994), mediation (Anderson and Narus, 1990), internal resolution (Assael, 1969), and smoothing (Ruekert and Walker, 1987).

- Coordination of the relationship is defined as the process by which participants in an inter-organizational relation seek to work together in a joint effort (Narus and Anderson, 1987; Morgan and Hunt, 1994) based on a set of tasks that each partner expects the other to perform (Mohr and Spekman, 1994). In addition, Mulford and Rogers define inter-organizational coordination as "the process whereby two or more organizations create and/or use existing decision rules that have been established to deal collectively with their shared task environment" (Mulford and Rogers, 1982, p. 9)

- Flexibility in the relationship refers to the extent to which partners respond to requests for changing circumstances (Gibson, Rutner and Keller, 2002).

- Formalization in the relationship refers to the degree to which rules prescribing behavior are formulated, as well as the extent to which role responsibilities are prescribed (Scott, 1987; Dahlstrom and Nygaard, 1999).

- Frequency of interaction is defined as the amount of contact between organizations, measured in relation to an organization's total contact with others (Mayhew, 1971; Hall, 2005).

- Importance of the relationship refers to the extent to which staff members of an organization perceive that the relationship is critical to the mission of the 
organization (Hall et al., 1977; Whetten and Szwajkowski, 1978; Hall, 1991; Bucklin and Sengupta, 1993).

- Inter-dependence refers to a partner's perception of its dependence relative to its partners' dependence on the relationship (Anderson and Narus, 1990).

- Organizational compatibility is considered as domain similarity and goal compatibility, which have been found to enhance the effectiveness of inter-organizational dyads (Van De Ven and Ferry, 1980; Ruekert and Walker, 1987). Organizational compatibility reflects complementarity in goals and objectives as well as similarity in operating philosophies and corporate culture (Bucklin and Sengupta, 1993).

- Participation in the relationship refers to partners in a relationship working together to plan all related activities (Mohr and Spekman, 1994) as well as taking part in major decisions (Devlin and Bleackley, 1988) and goal setting.

- Trust in the relationship is defined as the willingness to rely on an exchange partner in whom one has confidence (Morgan and Hunt, 1994).

$\mathrm{H}_{1}$ : Independent variables of trust, commitment, interdependence, coordination, communication, conflict resolution, participation, formalization, frequency of interaction, flexibility, importance of the relationship, and organizational compatibility are positively associated with the financial benefits of the relationship.

$\mathrm{H}_{2}$ : Dependent variable of financial benefits is well explained and predicted by the independent variables.

\section{METHODOLOGY}

This study focuses mainly on financial benefits of relationship marketing and considers the relationships of factors affecting financial benefits of relationship marketing. For this reason, the quantitative approach is the major method applied.

\section{Unit of Analysis, Population, and Sample Size}

The unit of analysis for this study was at the corporate level, with the target population of all international travel companies of Vietnam having relationships with Thai travel partners. This number of Vietnamese travel companies was obtained from a list provided by the office of Tourism Authority of Thailand (TAT) in Ho Chi Minh City, which consisted of 237 companies. Due to the small number of travel companies, this study used the entire population as the sample for the research. In 
order to make sure that the expected number of returned questionnaires was obtained, the researcher sent the survey questionnaires to all travel companies on the list except for the 17 travel companies in Ho Chi Minh City that the researcher had interviewed for the pretest procedure of the research. As a result, a total of 220 international travel companies received the survey.

\section{Questionnaire Design}

Most questions were formulated as statements on a five-point Likert-scale, ranging from 1 (strongly disagree) to 5 (strongly agree). First, the researcher reviewed the empirical literature related to relationship marketing and the inter-organizational relationship. An initial draft questionnaire was completed based on the literature review.

Next, the initial draft questionnaire was then reviewed by the researcher's colleagues in order to obtain comments on wording, corrections of sentences and statements, format, and scale construct during the preliminary qualitative phase. The questionnaire was read by an expert in tourism marketing and development formerly of TAT in Bangkok and two lecturers in the field of tourism. All contributing suggestions and comments for the draft questionnaire from colleagues, tourism experts, and academic experts in the field of tourism were carefully considered, and adjustments were made in order to produce a good survey instrument for the research. The questionnaire was once again carefully reviewed and approved by the supervisor of the research to obtain the final version. Then, the questionnaire was translated into Vietnamese by the researcher and reviewed by two professors in the School of International Tourism Management of Hong Bang University International to make sure that the translation was of good quality and understandable in Vietnamese. To determine the reliability of the measurement, the questionnaire was pretested with a group of 17 international travel companies having relationships with Thai travel partners in Ho Chi Minh City. The responses from the pretest were reviewed and analyzed. The reliability of the measures was tested with Cronbach's alpha coefficients. Only the measure of interdependence of the relationship had a Cronbach's alpha value of 0.679 , which is considered acceptable; all other variables were above 0.80 . Thus, all of the dependent and independent variables of this study had very good internal consistency.

In order to avoid the halo effect, nearly half of the statements in the questionnaire were reverse-worded. Finally, the questionnaire was sent to the target participants. 


\section{Data Collection}

The primary data were collected through the survey questionnaires, which were sent to 220 Vietnamese international travel companies having relationships with Thai travel partners. The questionnaire, enclosed with a postage paid pre-addressed return envelope, was filled in by a representative from each travel company. The survey instrument had a cover page issued by the office of TAT in Ho Chi Minh City that introduced the project and asked for assistance and cooperation from travel companies in providing appropriate information for the research.

\section{Dependent Variable of Financial Benefits}

Regarding financial benefits of the relationship between Vietnamese and Thai travel companies, this measure consisted of six items, as shown in Table 1. The first two items were adapted from the work of Medina-Munoz and García-Falcón (2000) and the other items were adapted from the literature review.

Table 1 Dependent Variable of Financial Benefits of the Relationship (FIBERE)

\begin{tabular}{ll}
\hline Construct & \multicolumn{1}{c}{ Items $\quad($ Cronbach's alpha $=.901 ;$ Pre-test: $\mathrm{N}=17)$} \\
\hline Financial & 1. We obtain more profit on sales from our travel partner \\
Benefits & 3. We receive appropriate commission levels from our partner \\
& 4. We can reduce market and tour research and development costs \\
& 5. We have new sources of revenue from our partner \\
6. We are satisfied with the financial benefits gained from the relationship
\end{tabular}

The reliability test of this measure in the pretest procedure showed a Cronbach's alpha coefficient of 0.901 . This value is very high, so it can be concluded that these items are inter-correlated and measure the same concept. When the data were fully collected for 114 cases, the reliability of this measure was tested again. This time, the Cronbach's alpha value was less than 0.70 . In order to obtain a Cronbach's alpha value greater than 0.70 , item 2 was excluded, resulting in a Cronbach's alpha of 0.707 , which is considered good internal consistency. For further analysis and testing hypotheses, the five remaining items were added to create a new variable.

In this study, content analysis, questionnaire design, pre-testing procedure, and reliability tests were applied to assess the validity of the measurement. In addition, the validity and reliability of the measurement were again consolidated through factor analysis for the independent variables, as described in the following section. 


\section{Independent Variables of Financial Benefits}

Exploratory factory analysis, which used the principal component extraction method and varimax rotation of 89 items in the group of 12 independent variables related to the factors affecting financial benefits, was conducted on the returned sample of 114 Vietnamese international travel companies that have relationships with partners in Thailand. Prior to running the analysis with the SPSS, the data were screened by examining the descriptive statistics on each item, inter-item correlations, and possible univariate and multivariate assumption violations. From this initial assessment, all variables were found to be continuous; variable pairs appeared to be bivariate normally distributed; and all cases were independent of one another. Consequently, the sample size $(n=114)$ was considered reliable for the factor analysis with a ratio of 11 cases per variable for the independent variables. The Kaiser-Meyer-Olkin measure of sampling adequacy was 0.703 for the independent variables indicating that the present data were suitable for principal components analysis. Similarly, Bartlett's test of sphericity was significant $(\mathrm{p}<.001)$, indicating sufficient correlation between the variables.

Using Kaiser-Guttman's retention criterion of eigenvalues greater than 1.0, a twelve-factor solution was conducted for the group of independent variables. The twelve factors accounted for $70 \%$ of the total variance. Nine factors were considered appropriate and were retained for further analysis (see Table 2).

Table 2 Summary of Independent Variables with Reliability Coefficients

\begin{tabular}{l|l|c|c}
\hline & \multicolumn{1}{|c|}{ Given Names } & $\begin{array}{c}\text { Number of } \\
\text { Items }\end{array}$ & Alpha \\
\hline Factor 1 & Trust in the relationship (TRUSTIR) & 23 & .971 \\
Factor 2 & Participation in the relationship (PARTIR) & 10 & .887 \\
Factor 3 & Commitment to the relationship (COMITIR) & 12 & .887 \\
Factor 4 & Frequency of Interaction (FREINTER) & 5 & .729 \\
Factor 5 & Organizational Compatibility (ORGCOMP) & 3 & .793 \\
Factor 6 & Formalization in the relationship (FORMIR) & 7 & .712 \\
Factor 7 & Interdependence of the relationship (INTERIR) & 2 & .844 \\
Factor 8 & Communication in the relationship (COMUNIR) & 2 & .715 \\
Factor 9 & Coordination of the relationship (COORDIR) & 2 & .708 \\
\hline
\end{tabular}


The rationale used in naming these nine factors was guided by the recommendations of Comrey and Lee (1992), who sorted factor weights in excess of 0.65 to drive the process of labeling and interpreting each factor. For instant, the first four items of TRUSTIR have highest loading values ranging from 0.885 to 0.898 , the second factor of PARTIR has four items with highest loading values ranging from 0.718 to 0.855 , etc.. The present factor model of this study was deemed the best solution due to its conceptual clarity and ease of interpretability.

\section{RESULTS AND DISCUSSION}

\section{Profile of International Travel Companies}

The international travel company profiles formed the overall sample of this research $(n=114)$. Descriptive statistics were run with a frequency procedure on the primary data. This confirmed that nearly $70 \%$ of the respondents were managers of travel companies, 36\% were directors of the company account, and 33.3\% were chiefs of marketing. In terms of location, Vietnam was geographically divided into three main regions: southern, middle, and northern.

The majority of travel companies (55.3\%) employed fewer than 50 staff members; $14 \%$ were medium size companies, and nearly $11 \%$ were large companies.

The tourism industry of Vietnam is considered new, so the high percentage (more than $75 \%$ ) of young companies (less than 10 years) is not surprising. Consequently, more than $88 \%$ of companies have established relationships with Thai partners for less than 10 years.

\section{Factors Affecting Financial Benefits of the Relationship}

In order to determine which factors have relationships with the dependent variable of financial benefits and to test hypothesis $\left(\mathrm{H}_{1}\right)$, Pearson Product-moment Correlation Coefficients ( $r$ ) were employed. Table 4 shows that there were significantly positive relationships between the dependent variable, FIBERE, and the independent variables, PARTIR, COMITIR, FREINTER, ORGCOMP, FORMIR, and COORDIR. Among these significant relationships, there were moderately positive correlations between PARTIR, COMITIR, FREINTER, COORDIR and FIBERE $(\mathrm{r}=.517, \mathrm{p}<.001, \mathrm{r}=.539, \mathrm{p}<.001, \mathrm{r}=.470, \mathrm{p}<.001$, and $\mathrm{r}=.383, \mathrm{p}<.001$, respectively). This means that the higher level of participation in the relationship, commitment to the relationship, frequency of interaction, and coordination of the relationship that an international travel company has with its partner, the higher level of financial benefits that it might receive. The variables of ORGCOMP and FORMIR had modestly positive correlations with FIBERE $(\mathrm{r}=.217, \mathrm{p}<.05$ and $\mathrm{r}=.237, \mathrm{p}<.05$, respectively). 
This means that high levels of organizational compatibility and formalization in the relationship are associated with a high level of financial benefits.

Table 3 Vietnamese International Travel Company Profiles $(\mathrm{N}=114)$

\begin{tabular}{|c|c|c|}
\hline & Frequency & Percentage \\
\hline \multicolumn{3}{|l|}{ Job Positions of Respondents } \\
\hline - Director of the company & 41 & 36.0 \\
\hline - Chief of marketing department & 38 & 33.3 \\
\hline - Second chief of marketing department & 9 & 7.9 \\
\hline - Staff of marketing (small companies) & 26 & 22.8 \\
\hline \multicolumn{3}{|l|}{ Locations of Companies } \\
\hline - South of Vietnam & 67 & 58.8 \\
\hline - Middle region of Vietnam & 15 & 13.2 \\
\hline - North of Vietnam & 32 & 28.1 \\
\hline \multicolumn{3}{|l|}{ Number of Full-time Staff } \\
\hline$-1-20$ & 63 & 55.3 \\
\hline$-21-40$ & 23 & 20.2 \\
\hline$-41-60$ & 10 & 8.8 \\
\hline$-61-80$ & 6 & 5.3 \\
\hline$-81-100$ & 4 & 3.5 \\
\hline$-101-120$ & 2 & 1.8 \\
\hline - Greater than 150 & 6 & 5.3 \\
\hline \multicolumn{3}{|l|}{ Number of Part-time Staff } \\
\hline$-0-20$ & 97 & 85.1 \\
\hline$-21-40$ & 9 & 7.9 \\
\hline$-41-60$ & 4 & 3.5 \\
\hline$-61-80$ & 1 & .9 \\
\hline$-81-100$ & 3 & 2.6 \\
\hline \multicolumn{3}{|l|}{ Age of Company } \\
\hline$-1-5$ & 43 & 37.7 \\
\hline$-6-10$ & 38 & 33.3 \\
\hline$-11-15$ & 16 & 14.0 \\
\hline$-16-20$ & 12 & 10.5 \\
\hline$-21-25$ & 1 & .9 \\
\hline - Greater than 25 & 4 & 3.5 \\
\hline \multicolumn{3}{|l|}{ Age of the Relationship } \\
\hline$-1-5$ & 66 & 57.9 \\
\hline$-6-10$ & 35 & 30.7 \\
\hline$-11-15$ & 11 & 9.6 \\
\hline$-16-20$ & 2 & 1.8 \\
\hline
\end{tabular}


The significant relationships between the dependent variable of FIBERE and the independent variables were consistently confirmed in the literature of relationship marketing and inter-organizational relation. For instance, the variable of COMITIR was deemed an important factor by Mohr and Spekman (1994), Morgan and Hunt (1994), Medina-Munoz and Garcia-Falcon (2000), Zabkar and Brencic (2004), Palmatier et al. (2007), and Nufer and Buhler (2011). In addition, the variable of PARTIR was supported by the work of Mohr and Spekman (1994). There was no significant relationship between TRUSTIR and FIBERE. This result was associated with the result found in the research of Palmatier and associates in 2007.

Mayhew (1971) and Hall (1991) suggest that frequency of interaction is an important factor affecting relationship effectiveness. This present study found that frequency of interaction is an important factor and has a positive significant relationship with financial benefits or financial outcomes. This indicates that a high frequency of interaction is associated with a high level of financial benefits. In this study, high frequency of interaction means often sending or receiving tourists to/from partners, meeting or contacting partners, and helping each other with services (e.g. airline booking, hotel reservations, museums, theaters, etc.).

Organizational compatibility was suggested to be a factor affecting financial benefits of the relationship. As shown in Table 4, the variable of organizational compatibility has a positive significant correlation with financial benefits of the relationship. This indicates that a high level of organizational compatibility is associated with a high level of financial benefits. This is consistent with the findings of Van De Ven and Ferry (1980) and Ruekert and Walker (1987), who found that domain similarity, goal compatibility, and organizational compatibility enhance the effectiveness of inter-organizational dyads.

In addition, factor of formalization is an essential predictor of relationship success (Bresser, 1988; Bucklin and Sengupta, 1993; Heide, 1994; Medina-Munoz and García-Falcón, 2000). According to Hoffman, Stearns and Shrader (1990), formalization relates to the extent to which rules, manuals, job descriptions, and standard operating procedures guide the relationship. This present study found a positive correlation between formalization of the relationship and financial outcomes, indicating that a high level of formalization is associated with high level of financial benefits.

This research showed that coordination has a significant positive effect $(\mathrm{r}=.383$, $\mathrm{p}<.001)$ on financial benefits/outcomes. Therefore, the more coordination between Vietnamese and Thai travel companies, the more financial benefits that may be 
obtained. Mohr and Spekman (1994), Frazier et al. (1988), and Medina-Munoz and García-Falcón (2000) suggest that a high level of coordination is associated with the success of inter-organizational relationships, which supports the present results.

Table 4 Descriptions and Variables' Correlations of the FIBERE Model

\begin{tabular}{llcccccccccc}
\hline & & FIBERE & 1 & 2 & 3 & 4 & 5 & 6 & 7 & 8 & 9 \\
\hline 1. & TRUSTIR & .083 & 1.000 & & & & & & & & \\
2. & PARTIR & $.517^{* *}$ & .083 & 1.000 & & & & & & & \\
3. & COMITIR & $.539^{* *}$ & $.163^{*}$ & $.698^{* *}$ & 1.000 & & & & & & \\
4. & FREINTER & $.470^{* *}$ & .137 & $.566^{* *}$ & $.510^{* *}$ & 1.000 & & & & & \\
5. & ORGCOMP & $.217^{*}$ & -.125 & $.335^{* *}$ & $.333^{* *}$ & $.332^{* *}$ & 1.000 & & & & \\
6. & FORMIR & $.237^{*}$ & $.473^{* *}$ & .242 & $.292^{*}$ & $.164^{*}$ & .153 & 1.000 & & & \\
7. & INTERIR & .022 & $.203^{*}$ & .012 & .089 & -.047 & -.115 & .073 & 1.000 & & \\
8. & COMUNIR & .043 & $.644^{* *}$ & .060 & .121 & .128 & .030 & $.461 * *$ & $.163 *$ & 1.000 & \\
9. & COORDIR & $.383^{* *}$ & .108 & $.330^{* *}$ & $.415^{* *}$ & $.273 * *$ & $.211^{*}$ & $.158^{*}$ & .038 & .121 & 1.000 \\
\hline & Mean & 18.98 & 77.94 & 39.18 & 48.59 & 19.47 & 11.03 & 22.96 & 6.71 & 6.98 & 7.66 \\
& SD & 2.94 & 23.83 & 4.84 & 5.14 & 2.63 & 1.74 & 4.40 & 1.79 & 2.00 & 1.17 \\
\hline
\end{tabular}

Note: $*$ Significant level at $\mathrm{p}<.05, * *$ Significant level at $\mathrm{p}<.001$

\section{Determinants of Financial Benefits of the Relationship}

tandard multiple regression was performed between FIBERE as the dependent variable and TRUSTIR, PARTIR, COMITIR, FREINTER, ORGCOMP, FORMIR, INTERIR, COMUNIR, and COORDIR as the independent variables to test the second hypothesis $\left(\mathrm{H}_{2}\right)$ of the study.

For greater clarity, a regression equation for the model of FIBERE was written using the standardized coefficients (Beta) in Table 5 as follows:

$$
\begin{aligned}
\text { FIBERE }= & -.002(\text { TRUSTIR })+.165(\text { PARTIR })+.232(\text { COMITIR }) \quad(\text { Eq. } 1) \\
& +.221(\text { FREINTER })-.046(\text { ORGCOMP })+.125(\text { FORMIR }) \\
& +.009(\text { INTERIR })-.081(\text { COMUNIR })+.175(\text { COORDIR })
\end{aligned}
$$

The model was statistically significant at $\mathrm{p}<.0005$ with $\mathrm{F}(9,113)=7.544$ and had an $\mathrm{R}$ squared value of .395 , which explains $39.5 \%$ of the variance in the FIBERE. This indicates that as a whole, all of the independent variables contributed to explaining nearly $40 \%$ of the variance of the FIBERE. 
Table 5 Coefficients between IVs and Financial Benefits of the Relationship

Standardized

Coefficients Sig. Correlations

(Beta)

(Part)

\begin{tabular}{lccc}
\hline & & & \\
TRUSTIR & -.033 & .763 & -.030 \\
PARTIR & .165 & .154 & .140 \\
COMITIR & .232 & .047 & .194 \\
FREINTER & .221 & .025 & .218 \\
ORGCOMP & -.046 & .598 & -.052 \\
FORMIR & .125 & .185 & .130 \\
INTERIR & .009 & .908 & .011 \\
COMUNIOR & -.081 & .439 & -.076 \\
COORDIOR & .175 & .041 & .198 \\
\hline
\end{tabular}

Note: Dependent Variable: FIBERE: Total financial benefits of the relationship

- Predictors: TRUSTIR, PARTIR, COMITIR, FREINTER, ORGCOMP, FORMIR, INTERIR, COMUNIR, COORDIR

- $\quad$ ANOVA: $F(9,113)=7.544$, Sig. $=000, p<.0005$

- $\quad$ Model summary: $\mathrm{R}^{2}=.395$

To compare the contribution of each independent variable to the FIBERE and to determine which variable made a significant unique contribution to the prediction of the FIBERE, standardized beta values $(\beta)$ and significant values (p) were used. Three of nine independent variables were included in the model, making a statistically significant unique contribution to the FIBERE with significant value $(p<.05)$. Among them was COMITIR, which had the largest beta value $(\beta=.232, \mathrm{p}<.05)$ and was considered the most important factor. The second most important factor was FREINTER $(\beta=.221, p<.05)$. The third key factor was COORDIR $(\beta=.175, \mathrm{p}<.05)$.

These three factors were significant in making unique contributions to the prediction of the FIBERE and contributed positive scores to the FIBERE. This means that every 1-standard deviation increase in COMITIR, FREINTER, and COORDIR contributed to an increase in the score of the FIBERE equal to the amount of the coefficient in front of it, controlling for other factors. In this case, every 1-standard deviation increase in the COMITIR, FREINTER, or COORDIR yielded an increase of.232, or .221, or .175, respectively when other variables were constant. 


\section{CONCLUSIONS}

The findings of this study suggest that in order to obtain good financial benefits from relationships with international travel partners, the managers of international travel companies should participate in planning and goal setting in the relationship; show more commitment or dedication to working with the travel partner; often send/receive tourists to/from partners, meet or contact partners, and help with other services; pay attention to organizational compatibility when setting up an alliance or partnering relationship with the travel partner; formalize the relationship with the partner; and have good coordination of the relationship with the travel partner.

The results of this study also present empirical evidence regarding the determinants of the financial benefits of the inter-organizational relationship marketing such as commitment to the relationship $(\beta=.232, \mathrm{p}<.05)$, frequency of interaction $(\beta=.221, p<.05)$, and coordination of the relationship $(\beta=.175, p<.05)$ which have significant effects on the dependent variable of financial benefits. Moreover, this study presents a comprehensive conceptual framework drawn from the literature of the relationship marketing and the inter-organizational relationship and provides a better understanding of financial benefits of the relationship between Vietnamese travel companies and Thai partners.

This study serves as an essential starting point for building a robust empirical base that would significantly increase knowledge in the field of relationship marketing study in general and in the field of financial benefit evaluation of inter-organizational relationship in particular. In this study, the data represent the view from respondents on only one side, but future research should collect comparable data from participants on both sides of the relationship. In addition, a similar study of the financial benefits of inter-organizational relationship marketing should be undertaken in other contexts, for example, hotels and travel agencies, universities, production companies, supplier and distribution companies, etc., in order to affirm the empirical results and obtain a better generalization of this research.

\section{ACKNOWLEDGEMENTS}

The author would like to express grateful thanks to the employees, officers, and especially to Mr. Huynh Dang Khoa from the Office of the Tourism Authority of Thailand in Ho Chi Minh City, Vietnam for their enthusiastic assistance and support in providing information and data collection for this study. In addition, the author also would like to thank Prof. Suchitra Punyaratabandhu, Graduate School of Public Administration, National Institute of Development Administration (NIDA), for her 
great advice and support so that this study could be successfully accomplished.

\section{REFERENCES}

Anderson, J. and Narus, J. (1990). A Model of Distributor Firm and Manufacturer Firm Working Partnerships. Journal of Marketing, 54(1), 42-58. http://dx.doi.org/10.2307/1252172

Arnett, D. B., German, S. D., and Hunt, S. D. (2003). The Identity Salience Model of Relationship Marketing Success: The Case of Nonprofit Marketing. The Journal of Marketing, 67(2), 89-105. http://dx.doi.org/10.1509/jmkg.67.2.89.18614

Assael, H. (1969). Constructive Role for Inter-organizational Conflict. Administrative Science Quarterly, 14, 573-581.

Berry, Leonard L. (1995). Relationship Marketing of Services - Growing Interest, Emerging Perspectives. Journal of the Academy of Marketing Science, 23(4), 236-245. http://dx.doi.org/10.1177/009207039502300402

Boyle, B., Dwyer, F.R., Robicheaux, R.A. and Simpson, J.T. (1992). Influence Strategies in Marketing Channels: Measures and Use in Different Relationship

Structures. Journal of Marketing Research, 29 (4), 462-473. http://dx.doi.org/10.2307/3172712

Bresser, R. K. F. (1988). Matching Collective and Competitive Strategies. Strategic Management Journal, 9(4), 375-385. http://dx.doi.org/10.1002/smj.4250090407

Bucklin, L. P. and Sengupta, S. (1993). Organizing Successful Co-marketing Alliances. Journal of Marketing, 57(2), 32-46. http://dx.doi.org/10.2307/1252025

Colgate, M. R. and Danaher, P.J. (2000). Implementing a Customer Relationship Strategy: The Asymmetric Impact of Poor Versus Excellent Execution. Journal of Academy of Marketing Science, 28(3), 375-387. http://dx.doi.org/10.1177/0092070300283006

Comrey, A. L. and Lee, H. B. (1992). A First Course in Factor Analysis. Hillsdale, NJ: Erlbaum.

Cummings, T. (1984). Transorganizational Development. Research in Organizational Behaviour, 6, 367-422.

Dahlstrom, R. and Nygaard, A. (1999). An Empirical Investigation of Ex Post Transaction Costs in Franchised Distribution Channel. Journal of Marketing Research. 36(2), 160-170. http://dx.doi.org/10.2307/3152090 
De Wulf, K., Odekerken-Schröder, G. and Iacobucci, D. (2001). Investments in Consumer Relationships: A Cross-Country and Cross-Industry Exploration. Journal of Marketing, 65(4), 33-50. http://dx.doi.org/10.1509/jmkg.65.4.33.18386

Deutsch, M. (1969). Conflict: Productive and destructive. Journal of Social Issues, 25(1), 7-41. http://dx.doi.org/10.1111/j.1540-4560.1969.tb02576.x

Devlin, G. and Bleackley, M. (1988). Strategic Alliances: Guidelines for Success. Long Range Planning, 21(5), 18-23. http://dx.doi.org/10.1016/0024-6301(88)90101-X

Dwyer, F. R., Schurr, P. H., and Oh, S. (1987). Developing Buyer-Seller Relationships. Journal of Marketing, 51(2), 11-27. http://dx.doi.org/10.2307/1251126

Frazier, G., Spekman, R., and O’Neal, C. (1988). Just-in-Time Exchange Relationships in Industrial Markets. Journal of Marketing, 52(4), 52-67. http://dx.doi.org/10.2307/1251633

Ganesan, S. (1994). Determinants of long-term orientation in buyer-seller relationships. Journal of Marketing, 58(2), 1-19. http://dx.doi.org/10.2307/1252265

Ghosh, A. K., Joseph, W. B., Gardner, J. T. and Thach, S. V. (2004). Understanding industrial distributors' expectations of benefits from relationships with suppliers. Journal of Business and Industrial Marketing, 19(7), 433-443. http://dx.doi.org/10.1108/08858620410564382

Gibson, B.J., Rutner, S.M. and Keller, S.B. (2002). Shipper-carrier partnership issues, ranking and satisfaction. International Journal of Physical Distribution and Logistic Management, 32(8), 669-681. http://dx.doi.org/10.1108/09600030210444917

Hall, R. H., ed. (2005). Organizations: Structures, Processes, and Outcomes. Englewood Cliffs, NJ: Prentice-Hall.

Hall, Richard H. (1991). Interorganizational relationships. Organizations: Structures, processes, and outcomes. Englewood Cliffs, NJ: Prentice-Hall.

Hall, R. H., John P. C., Peggy C. G., Paul V. J., and Roekel, M. V. (1977). Patterns of Interorganizational Relationships. Administrative Science Quarterly, 22(3), 457-474. http://dx.doi.org/10.2307/2392183

Heide, Jan B. (1994). Interorganizational Governance in Marketing Channels. Journal of Marketing, 58(1), 71-85. http://dx.doi.org/10.2307/1252252

Hoffman, A. N., Stearns, T. M., and Shrader, C. B. (1990). Structure, context and centrality in inter-organizational networks, Journal of Business Research, 20(4), 333-347. 
Iglesias, O., Sauquet, A., and Montana, J. (2011). The role of corporate culture in relationship marketing. European Journal of Marketing, 45(4), 631-650. http://dx.doi.org/10.1108/03090561111111361

Johanson, J., Hallen, L., and Seyed-Mohamed, N. (1991). Interfirm Adaptation in Business Relationships. Journal of Marketing, 55 (2), 29-37.

Kalwani, M. U. and Narayandas, N. (1995). Long-term Manufacturer-Supplier Relationships: Do They Pay?. Journal of Marketing, 59(1), 1-16. http://dx.doi.org/10.2307/1252010

Kim, B. Y, Oh, H. and Gregoire, M. (2006). Effects of Firms' Relationship-Oriented Behaviors on Financial Performance: A Case of the Restaurant Industry. Journal of Hospitality and Tourism Research, 30(1), 50-75. http://dx.doi.org/10.1177/1096348005284487

Mayhew, Leon. (1971). Society: Institutions and Activity. Glenview, I11.: Scott Foresmand and Company.

Medina-Munoz, D. and García-Falcón, J. M. (2000). Successful Relationships between Hotels and Agencies. Annals of Tourism Research, 27(3), 737-762. http://dx.doi.org/10.1016/S0160-7383(99)00104-8

Mohr, J. and Spekman, R. (1994). Characteristics of Partnership Success: Partnership Attributes, Communication Behavior, and Conflict Resolution Techniques. Strategic Management Journal, 15(2), 135-152. http://dx.doi.org/10.1002/smj.4250150205

Morgan, Robert M. and Hunt, S. D. (1994). The Commitment-Trust Theory of Relationship Marketing. Journal of Marketing, 58(3), 20-38. http://dx.doi.org/10.2307/1252308

Mulford, C. L., and Rogers, D. L. (1982). Definitions and Models. In D. L. Rogers and D. A. Whetten (Eds.), Interorganizational Coordination: Theory, Research, andImplement (pp. 9-31). Ames, IA: Iowa State University Press.

Narus, J. and Anderson, J. (1987). Distributor Contributions to Partnerships with Manufacturers. Business Horizons, 30(5), 34-42. http://dx.doi.org/10.1016/0007-6813(87)90077-2

Nufer, G. and Bühler, A. (2011). Relevant factors for successful relationships between professional sporting organizations and their sponsors. Journal of Physical Education and Sports Management, 2(3), 26-31. http://www.academicjournals.org/jpesm/PDF/Pdf2011/July/Nufer\%20and\%20Bu hler.pdf 
Pallant, Julie. (2005). SPSS Survival Manual: A Step by Step Guide to Data Analysis Using SPSS, Version 12 ( ${ }^{\text {nd }}$ Ed.), Buckingham: Open University Press.

Palmatier, R., Scheer, L., Evans, K., and Arnold, T. (2008). Achieving relationship marketing effectiveness in business-to-business exchanges. Journal of the Academy of Marketing Science, 36(2), 174-190. http://dx.doi.org/10.1007/s11747-007-0078-5

Palmatier, R.W., Dant, R. P. and Grewal, D. (2007). A Comparative Longitudinal Analysis of Theoretical Perspectives of Inter-organizational Relationship Performance. Journal of Marketing, 71(4), 172-194.

Ruekert, R., and Walker, O. (1987). Marketing's interaction with other functional units: A conceptual frramework and empirical evidence. Journal of Marketing, 51(1), 1-19. http://dx.doi.org/10.2307/1251140

Scott, W. Richard. (1987). Organizations: Rational, Natural, and Open Systems $\left(2^{\text {nd }}\right.$ ed.). Englewood Cliffs, NJ: Prentice-Hall.

Sheth, J.N. and Parvatiyar, A. (1995). Relationship Marketing in Consumer Markets: Antecedents and Consequences. Journal of the Academy of Marketing Science, 23 (4), 255-271. http://dx.doi.org/10.1177/009207039502300405

Thomas, K. W. (1976). Conflict and conflict management. In M. D. Dunnette, (Ed.), Handbook of industrial and organizational psychology, (pp. 889-935). New York, NY: John Wiley \& Sons.

Van De Ven, A. H., and Ferry, D. L. (1980). Measuring and assessing organizations. New York, NY: John Wiley and Sons.

Weitz, B. A. and Jap, S. D. (1995). Relationship marketing in distribution channels. Journal of the Academy of Marketing Science, 23(4), 305-320. http://dx.doi.org/10.1177/009207039502300411

Whetten, David A. and Szwajkowski, Eugene. (1978). Relational Variables in Inter-organizational Relations: Conceptual and Methodological Issues, Working Paper. Illinois, IL: University of Illinois Press.

Wilson, D.T. (1995). An integrated model of buyer-seller relationships. Journal of the Academy of Marketing Science, 23(4), 335-45. http://dx.doi.org/10.1177/009207039502300414

Zabkar, V. and Brencic, M. (2004). Values, trust and commitment in business-to-business relationship: a comparison of two former Yugoslav markets. International Marketing Review, 21(2), 202-215. http://dx.doi.org/10.1108/02651330410531402 